Gerlinde Glaser

\title{
SWINGING: A RITUAL FOR HEALTH AND PROSPERITY PERFORMED IN RUSSIA AND ON THE BALKANS
}

Abstract: Swinging not only symbolizes spring awakening of nature, but is also believed to magically stimulate the fertility of the earth. On the one hand, the dynamic construction of the big Easter swing is based on the myth of the transfer from one world to the other, while on the other hand, the secret ritual of installing the swings and the partaking in erotic games suggest a symbolic re-enactment of the cosmogonic myth. Furthermore, in a traditional worldview swinging may be considered as a method of overcoming fatal indefinition and unpredictability.

Keywords: swinging, Spring, Gjurgovden, health, initiation.

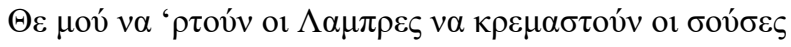

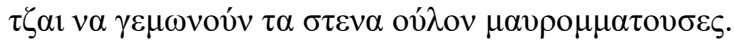

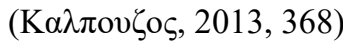

(Come Easter and the swings will be hung up,

the narrow alleys will be full of dark-eyed maidens).
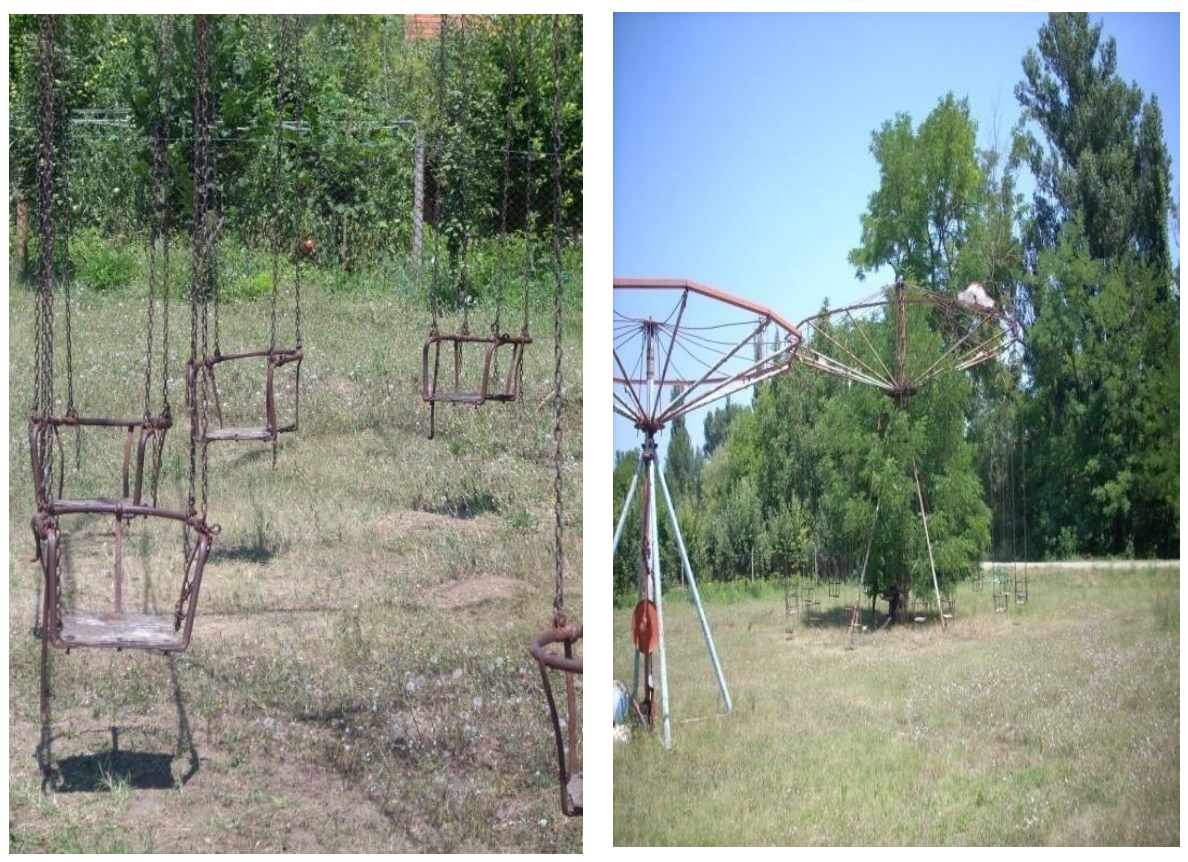

Photo 1. Swings in Chelopek, Macedonia 


\section{Swinging for Vegetational Revival}

The ancient tradition of spring swinging must be understood as a magic undertaking for the increase of land fertility and a symbolic stimulation of vegetational revival and reproduction. Erotic songs and games accompanying the swinging ceremony must be seen within this context, while the rhythmic motion of swinging itself may, apart from other interpretations, stand as a metaphor for coupling (Shternberg, 1936, 446).

The cyclic movement of the sun is mimed by the circular motion of the swing on a vertical and horizontal axis: "Swinging is a universal symbol of cyclical time" (Konakov, 1993, 59). Archaic belief-systems have therefore associated swing movement with resurrection. So, as a rule, swing making takes place in spring with solar action increasing. Moving on a swing symbolizes spring awakening of nature and secures the stability of the rhythm of the universe.

Figurines of the Bird Goddess type rendered with perforations, apart from being hung up in shrines etc., might have been used in ritual swinging. Furthermore, in ancient Greece swinging was known in connection with the festival of Aiora (Nilsson, 1950, 331-32; Gimbutas, 1992, 65). A swinging figurine attached to pillars portrayed in clay, found in Agia Triada, Crete, is doubtlessly connected with the spring fertility rite.

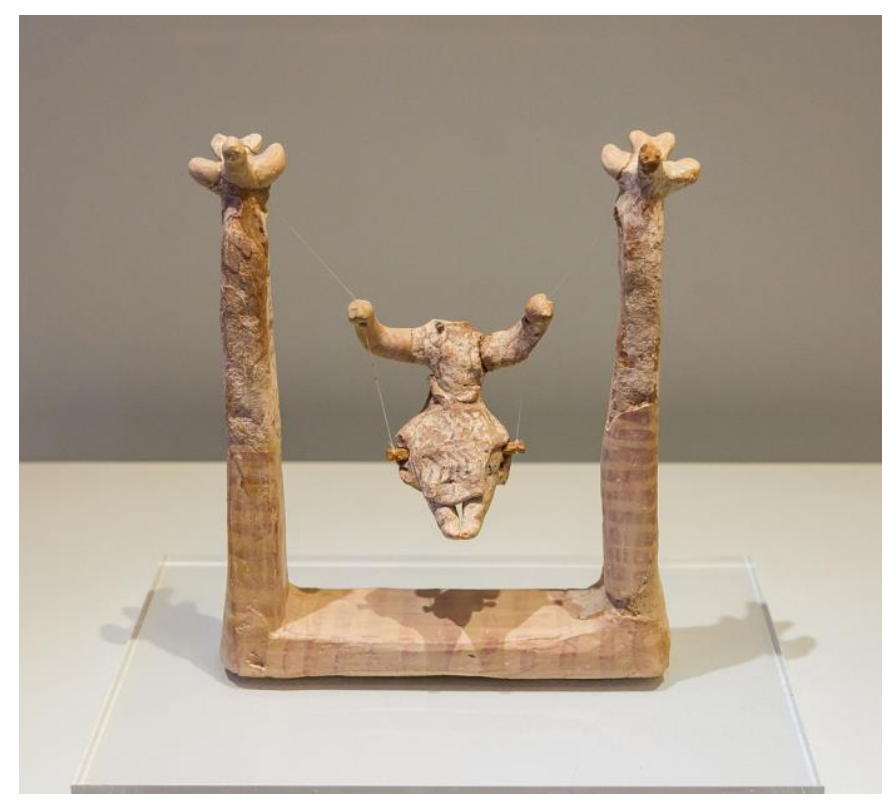

Photo 2. Girl on a Swing, Archaeological Museum, Heraklion, Crete 


\title{
1.1. Easter Swinging. The North-Russian Easter Swing
}

... However, accepting the proposition that heaven and earth were connected in the minds of our early ancestors as one cosmocentric whole, which offered meaning and sustenance to their existence, then what we see today with rituals and ceremonies most assuredly originated from a time unknown: a time when language began and meaning was being developed (Van De Bogart, 2013, 25).

Swinging is popular among the Komi people in North-East Russia, starting in spring and lasting till summer, from Shrovetide to Trinity. Traditionally, the young males set up the swings and the young females supply the ropes, ritually woven from young birch rods or hemp. The big Easter swing, however, is set up on the eve of Light Sunday before dawn at the village centre or near the riverside; it is only for unmarried males and females to swing on the big Easter swing during Easter week. The whole performance of swinging points to some pre-marriage initiation ritual, where the young males may even be mortally challenged. Those in the Russian song seem to be prepared to suffer ritual death:

\author{
Podoshli my k tem kacheljam... \\ Od kacheljami lezhat, \\ Vytjanyvshis' v strashnyj rjad, \\ Kosti sgnivshie ljudskie, \\ Kosti svezhie ljudskie... \\ Sami srjazu my podumali: \\ “Znachit zdes' oni gostej \\ na kacheljach etich gubjat..."
}

(We came to this swing and saw the terrible heap of fresh and rotten human bones. So, we thought that this is the place, where they destroyed their guests) (Sharapov, Nesanelis, 1995, 180).

Easter swinging, however, is not only concerned with the increase of solar energy and the revival of nature but also with establishing a connection to the Other World. The young males on the Easter swing, swinging on the axis East-West, act as mediators between the two worlds as, according to an ancient belief, only during the Easter week the gates to the Other World are open. Commemoration of the dead is therefore part of the Easter ritual. With a warning of the resin pit, through which the road to the Beyond is believed to lead, young males, in keeping with the old myth, are cautioned against swinging after the Easter week. So, it seems that Easter swinging as a leave-taking rite closes the wintery season and stimulates the spring and summer cycle (Sharapov, Nesanelis, 1995, 180).

The dynamic construction of the big Easter swing, the authentic material used (poles and the sitting-board are taken from a chum frame - a Komi cone-shaped hut, or fence or the floor of a shed) and the final demolition of the swing at the end of the Easter period symbolizes „destruction-reconstruction“ of the house, i.e. the mythological model of world creation (Sharapov, Nesanelis, 1995, 178-179). Moreover, the secret rite of swing making, the erotic nature of swing games (maidens are to say the name of their supposed husbands at the maximum height of 
the swing motion on the Easter swing) and the promise of free access to the cosmic zones (by overcoming the border between "top" and "bottom") characterize swinging as a dramatization of the cosmogonic myth.

The last day of the Easter week, when the actors of the swing games are presented coloured eggs as symbols of revival, may be compared to the final moment in the mythological scenario of world creation. Here is the connection to the imagery of the cosmic swing attached to the walnut tree. While swings are removed after a certain period of time the poles or swing supports, which symbolize the idea of static integrity of the universe and the re-established order of things, i.e. the balance of the cosmic regions, stay in place all year up to the next Easter (Sharapov, Nesanelis, 1995, 181). The latter practice reflects the religious concept of the World Tree rising at the centre of the earth and connecting the three cosmic regions with its branches touching the sky and its roots going down to the underworld. On the one hand, it represents the universe in continual regeneration, and on the other hand, it symbolizes the sky or the planetary heavens. Furthermore, it is related to the ideas of creation, fecundity and initiation, and finally to the idea of reality and immortality. Thus, the World Tree becomes a Tree of Life and Immortality as well (Eliade, 1992, 270-271).
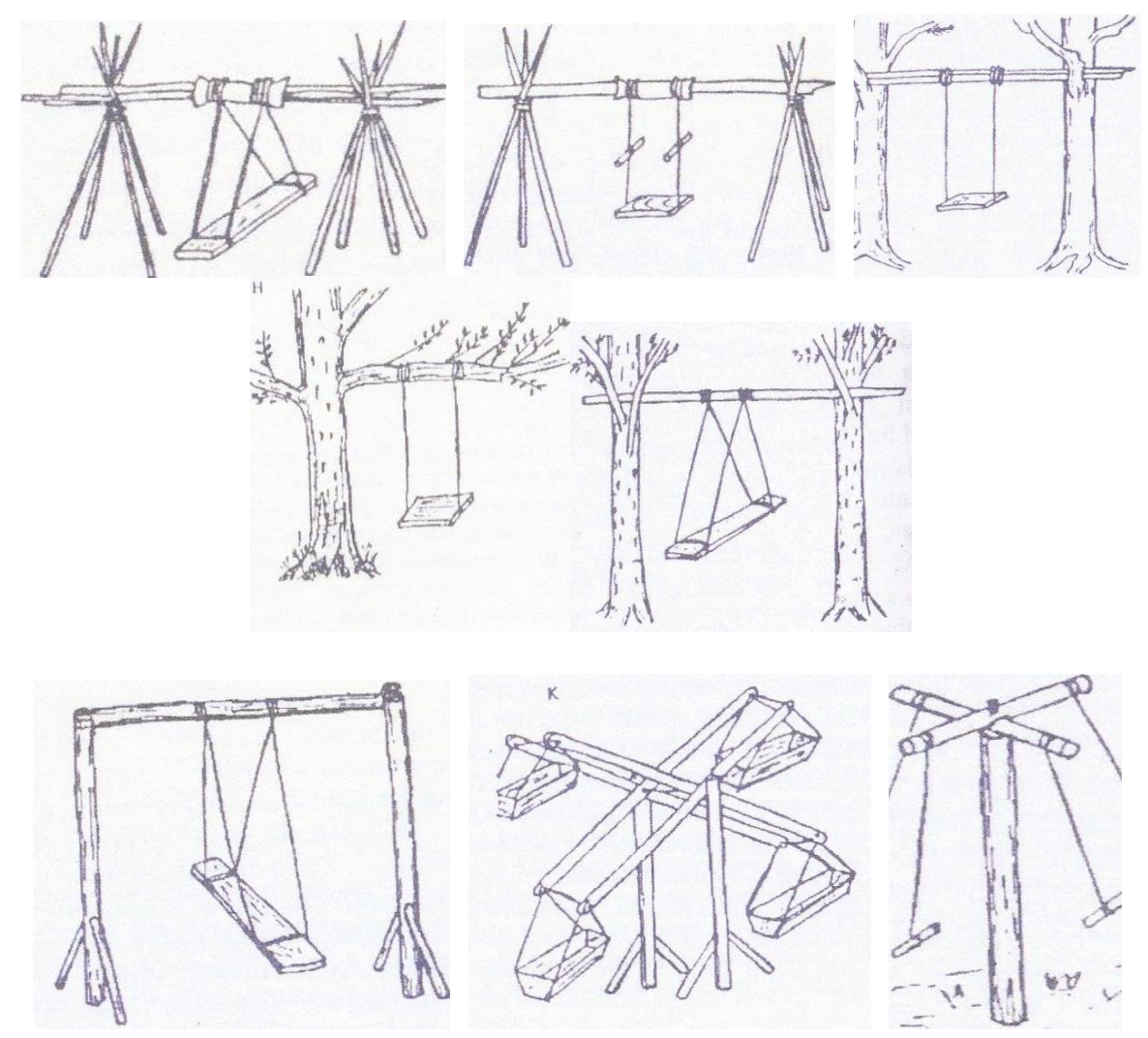

Illustration 1. Swings in traditional Komi culture (Sharapov, Nesanelis, 1992, 182-183) 
The concept of fecundity and growth is also inherent in a fertility ceremony, where the Siamese King Hop, the Temporary King, watches the Brahmans rushing through the air in a swing suspended between two tall masts, each some ninety feet high. The higher the priests swing the higher will grow the rice (Frazer, 1987, 285, 289).

A similar custom has been observed among the Lettish people: for the ceremony is described as a harvest festival, and swinging is practiced by the Letts of Russia with the avowed intention of influencing the growth of the crops. In the spring and early summer, between Easter and St. John's Day (the summer solstice), every Lettish peasant is said to devote his leisure hours to swinging diligently; for the higher he rises in the air, the higher will his flax grow that season (Frazer, 1987, 289).

Initiation rituals concerned with swinging or "tossing" serve a similar purpose of balancing or stabilizing. The "tossing" of novices in the context of an Australian initiatory ordeal may be interpreted as "offering the novice to the sky god or as symbol of ascension" (Eliade, 2009, 46).

Suspension between heaven and earth as practiced in the swinging and initiation performance or the observation of certain taboos involves mysterious energy, which may either prove beneficent or maleficent. An initiation ritual among South American communities forbids girls to touch the ground; therefore, the novices spend their days and nights in hammocks (Eliade, 2009, 81). The general purpose of this rule is to keep them suspended between heaven and earth for their own safety and for the safety of others, as the girls are seen as charged with a powerful force, which may prove harmful both to themselves and to all with whom they come in contact. This uncleanness of girls at puberty may have a similar effect as the sanctity of holy men: When divine personages, unobservant of the precautions, touch the ground, their sacred energy may discharge itself violently on their surroundings and thus be lost for future performances (Frazer, 1987, 606f.).

\subsection{Swinging on St. George's Day}

Swinging for health, prosperity, love and beauty is one of the magic practices performed on St. George's Day in Macedonia and Bulgaria. After the festive meal the installation of the swings commence. Flaxen ropes woven by the Lazar maidens are fastened to spring-green trees for everybody to swing.

The sun's involvement adds a mythological dimension to the drama: At the event of his wedding the sun sends down to earth his rays in the shape of a golden swing so as to abduct the fair maiden Grozdana:

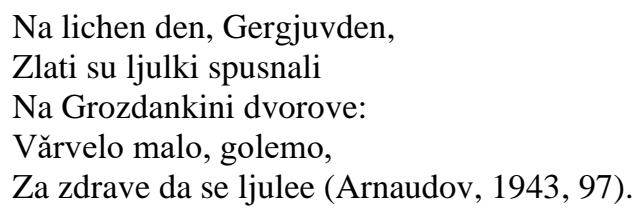

(On bright George's Day, 
the sun lowers his golden swings

into Grozdana's courtyard:

Young and old are gathering

to swing for their health).

The maiden is attired in fresh aromatic herbs when mounting the swing. She is ritually struck with a willow rod, which is to secure her health, and she is to pronounce the name of her dear one. At the same time the young man is expected to watch over or take part in the swinging of his beloved one.

Jod granka v granka, aj Gjurgje le, junaku v raka,

vikum vikashe fidanli Jovan:

Krotko frlajte moeto mome,

da ne mi padni, da se jotepa,

jazhe jazhlivo, drvo crvlivo,

drvo shuplivo, mesto kamlivo!

Chekaj ja, chekaj, ju desna raka,

ju desna raka, aj Gjurgje le, ju leva noga (Nanevski, 1971, 98).

(From branch to branch, hey George, into the young male's arms,

young Jovan exclaimed:

Tenderly swing my maiden,

so she does not fall or hit herself,

the rope is brittle, the tree worm-eaten,

the tree is hollow, the ground stony;

Wait, wait, give me the right hand,

The right hand, George, the left leg).

As a further part of the custom forthcoming weddings are guessed at. On the eve of St. George's (or occasionally at New Year's) the swinging maidens ask themselves, "Who is my dear one? Let him come at night, so we can swing together" (Decheva, Komitska, 1999, 60). In Ohrid at the occasion maidens smear their hair with raw egg, then cut off some of it and bury it under a vine root so as to make the vine grow as fast as their hair grows: "Kakto raste loznicata, taka da mi raste $\mathrm{i}$ kosata" (Arnaudov, 1943, 99). When the swinging takes place on a plum or willow tree the maidens put "lepavec" (goosegrass) on their heads so the males will stick to them: "da se prilepuvaat za niv (momite) momcite". They girdle themselves with "debelika" (white bryony) so as to grow a big stomach: "a so debelika se opashuvale, za da se zdebelele" (Shapkarev, 1976, 4, 121). The Easter egg they put in their pocket is meant to turn them as red and plump as the egg (Shapkarev, 1976, 4, 121). Other Macedonian customs have the young females hold a red egg, a silver object, i.e. a ring, a sprig of nettle or hop and a stone in their hands for some spring fertility magic (Risteski, 1985, 106f.). Once on the swings the maiden sings:

Kako shto e crveno jajceto taka sum jas crvena, kako shto e koprivata na Gjurgjovden vesela, taka jas da bidam cela godina vesela; kako shto se goe ogojkata taka jas da se gojam, kako shto e cvrst kamenot taka da sum jas crvsta (Risteski, 1985, 106f.). 
(I will be as red as the red egg, as joyful as the nettle is on George's Day I will be all year; as the hop grows fat, I will grow fat, as tough as is the stone I will be).

St. George's swinging with its inherent love magic is not only for the youth who intend to get married soon but also for the elder people from the community, who swing for a rich harvest.

The image of two trees growing into each other forming "gates" or an "arch" point to the most archaic variety of the Easter swing. It is a metaphor for a border between the World of the Living and that of the Dead, which the hero in his quest for enlightenment must cross:

...Kieferbaum spricht zu einer Fichte:

Wachse schnell, du meine liebe Fichte, unsere Wurzeln soll'n zusammenwachsen, deine Wipfeln sollen mich umschlingen. Jung und Maid woll'n eine Schaukel binden ...

(Decheva, Komitska, 1999, 60).

(...the pine-tree tells the fir-tree:

Grow fast, my dear fir-tree, our roots shall grow into each other, your tops shall embrace me.

A young male and a maiden will fasten a swing... ).

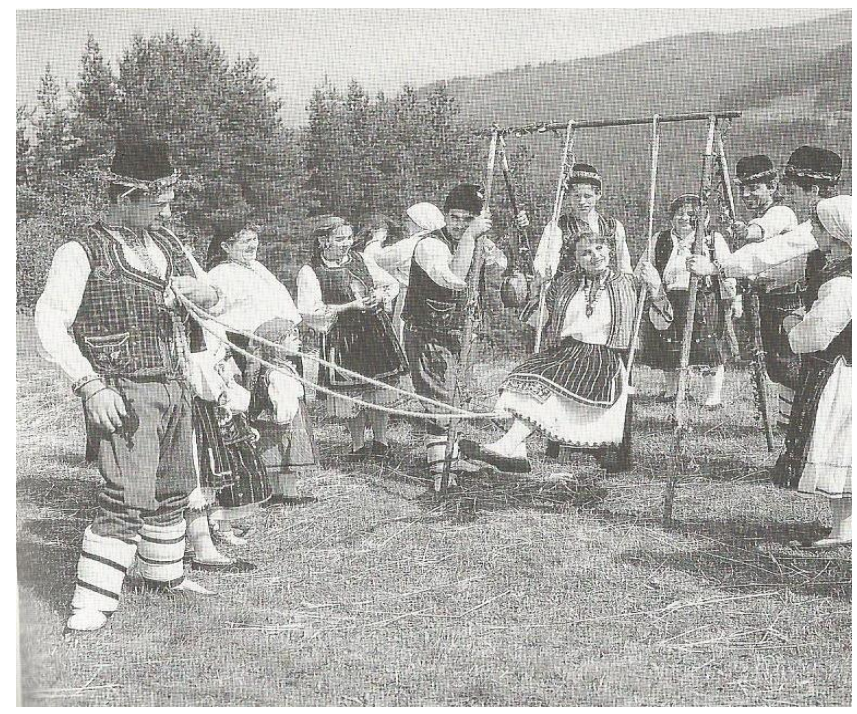

Photo 3. Swinging on George's Day in Bulgaria (Decheva, Komitska, 1999, 61).

The young male may sing the following song:

Gjelo se lula

Od granka v granka 
Na Stojna vo skutot

Stojna go gle'a

I go shiri skutot

(Risteski, 1985, 107).

(Gjelo swings

from branch to branch

into Stojna's lap,

Stojna looks at him

and opens her lap).

This is sung about the swinging maiden:

Petkana se lula

Od granka v granka

Na Gjela vo skutot

Gjelo ja gle'da

I go shiri skutot

(Risteski, 1985, 107).

(Petkana swings

from branch to branch

into Gjela's lap,

Gjela looks at her

and opens his lap).

\subsection{Christmas Swinging in Northern Greece}

In the Pindos Mountains (Koutsoufliani) swinging starts on the first Christmas holiday and is carried on until the onset of carnival. It is practised from early afternoon until early evening when the villagers have to see to their cattle. Swinging is considered everyman's pastime (Propp, 1963, 137).

Alas, the inherent love magic surrounding the festivities may lead to tragedy, i.e. a fateful family break-up involving infidelity, elopement and vendetta, which is the subject-matter of the tune the maidens strike up when fastening the swings:

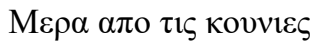

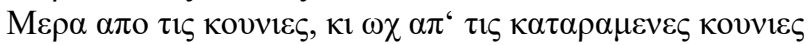

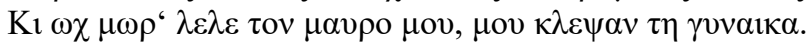

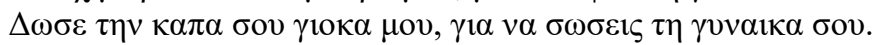

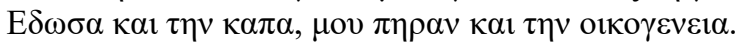

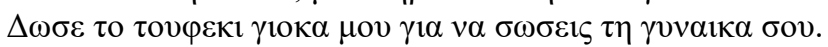

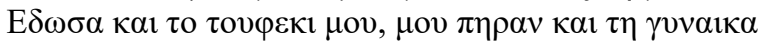

(Dietrich, Kahl, Sarros, 2001, 214-216).

(Day of the swings.

Day ot the swings, day of the damned swings,

And I, wretched I was robbed of my wife.

Give me your cloak, my son, so you can rescue your wife. 
I have given up my cloak, and then they even took my family.

Give me the gun, my son, so you can rescue your wife.

I also gave them my gun, and they took my wife).

The ropes taken from home are fastened on the highest and strongest branch of the tree, oak, walnut or mulberry; then a piece of felt is put on the rope so it won't cut into the backside of the swinger; another rope is fastened under the piece of fabric, which, if pulled, sets the swinger in motion.

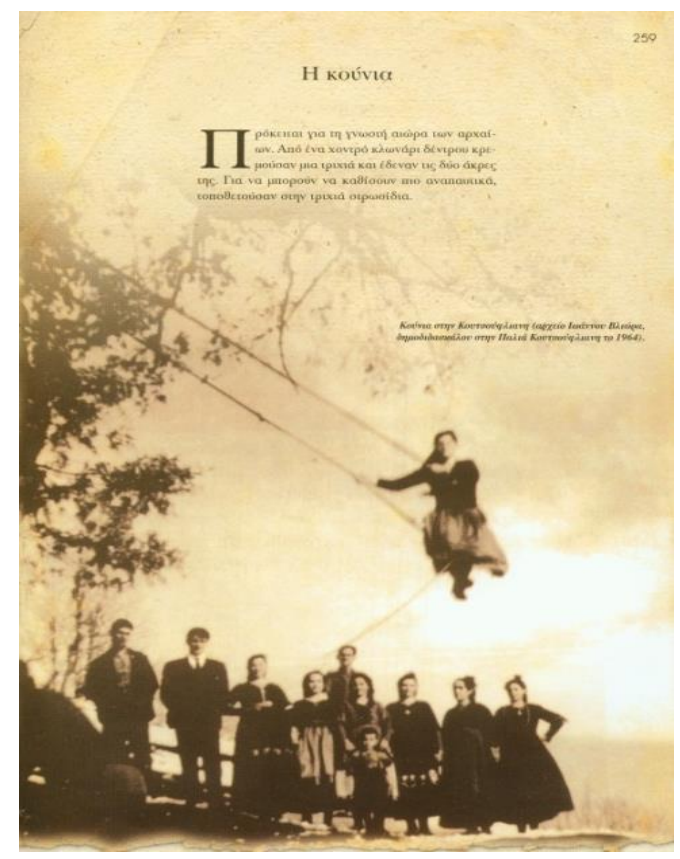

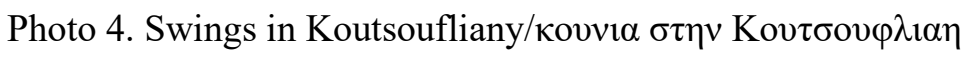

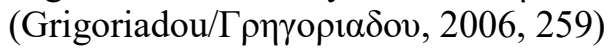

Swinging is performed as a pre-marriage rite with young males trying to spot prospective brides. Moreover, maidens and males are closely observed by their elders for glances, touches and secret messages passed between the swingers in order to guess at forthcoming weddings (Dietrich, Kahl, Sarros, 2001, 217-219).

Ritual swinging in North Russia and the Balkans marks the return of the solar activity and fertility and is to restore the cosmic order. Furthermore, it is understood to initiate young females and males into the secrets of marriage.

\section{Swinging the Baby}

On the third evening after the birth of the child the midwife assisted by dedicated siblings performs the swinging of the new-born child in the Gevgelija and Solunsko region: "Na tretata vecher go pravat zaluluvanjeto na deteto od babata, shto go babila i od dve drugi deca" (Shapkarev, 1976, 4, 23). The baby, clad in its 
father's shirt, is swung three times for its general well-being and good fortune: "Babata zaedno s dvete deca go stava novorodenoto detence vo koshulata i go zaluluvaat do tripati blagoslovuvajkji go istovremeno: da bide srekjno..." (Shapkarev, 1976, 4, 24).

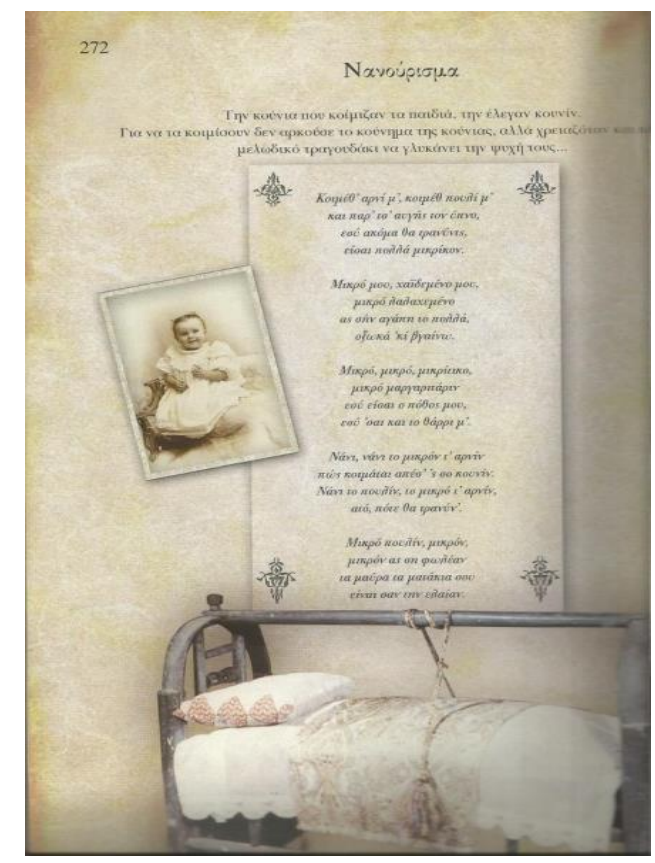

Photo 5. Cradle (Grigoriadou/Г $\rho \gamma$ $\gamma$

A further measure for the child`s health is the breaking and sharing of the birth cake.

In folkloristic texts fairy mothers look out for young females and by assigning them the role of midwife make them perform the sacred task of swinging their newborn children:

Mori Jovo, mome Jovo!

Ne najde li nejde voda

Nejde voda, nejde senka, da omijesh belo lice, belo lice ot praove, da omijesh crni ochi, crni ochi od s'zove? Tuku stana, ta si ojde Na planina, na Vlaina, $\mathrm{Na}$ samovilsko ezere? Tamo najde dve nevesti, dve nevesti, samovili, de banaa malki deca, malki deca pelenčina. 
Ta na Jova govorea:

Sestrice le, mori Jovo, ajde, Jovo, s nas da idesh, da ni banash mashki deca, da gi banash da gi lulash, malki deca pelencheta... (Sazdov, 1982, 37).

(Jova cannot find water or shade, to wash her white face, to wash off the dust, to wash her black eyes, to wash off her tears.

So she sets out

for the Vlaina mountains

to the fairies" lake.

There she meets two young fairy mothers

bathing their new-born children.

They ask Jova to come with them,

to bathe and swing their young... ).

Mary like any woman in childbed adheres to the ritual of swinging the baby for good luck. The maiden, who in her role as midwife carries out the swinging at the gathering around the birth cake, is rewarded magic garments:

Vikala e malka moma

Da si Boga poljuljava.

Tja e dala devet rizi,

Devet rizi koprineni

I deseta suo zlato.

Otishla e malka moma

Snoshchi vecher na kladenec,

Pa gja pitat malki momi:

- De si zela tazi riza,

Tazi riza koprinena?

- Dala mi gja Bozha majka,

Che săm Boga poljuljala

(Stoin, 1928, I, 4, 19).

(She called for the young girl to swing God.

She gave her nine garments, nine silken garments

and the tenth of pure gold.

In the evening the young girl went to the village well, where the other maidens asked,

"Where did you get the silken dress from?"

"God's mother gave it to me,

because I was swinging the young god). 
Ja săm moma nad momite,

Kje si imam devet rizi,

Devet rizi koprineni

I deseta suo zlato.

Cheva ne săm sama prela,

Sama prela, sama tkala,

Sama tkala, sama shila:

Dala mi gi Bozha majka,

Che săm Bogu poljuljala,

Poljuljala, podărzhala.

(Stoin, 1928, I, 20, 87).

(I am the first among the girls,

because I have nine dresses,

nine silken ones

and the third one of pure gold.

I did not weave

or sew them myself:

God's mother gave them to me,

Because I was swinging

and cuddling the young God).

Po polici - se zvezdici,

Na gărdite - jasen mesec,

Na pleshtite - jasno slănce

Darila me Bozhja majka,

Koga rodi mlada Boga,

Ta pozvala site zheni,

Site zheni na pogacha,

I ja ojdoh sos majka mi;

Rasplaka se mlada Boga,

Ta zaljuljah mlada Boga

U ljuljajka pozlatena,

Ta mi dari toj koshuljka

(SbNU, 1889, III, 20-21).

(At the hem the stars,

on the bosom the bright moon,

on the shoulders the bright sun

...

A present of God's mother,

when she gave birth to the young God,

she called all the women to share her birth cake,

and I went there with my mother;

when the young god began to cry,

I swung him

In his golden cradle,

She gave me the shirt). 
The following lines of a Komi song about the archaic technique of swing making are echoed in Mary's endeavour when on the green lilac mountain she makes a cradle for her child, fastens it to two twigs of lilac and rocking him, sings a lullaby.

Raskachaem my chodkuju kachel',

Chto na vos'mi prjamych zherdjach,

Raskachaem ljul'ku chetyrechuglovuju...

(Komi narodnye pesni, 1968, 54).

(We get a swing going well.

The swing, which is staying on eight straight poles.

We swing a cradle with four corners... ).

Bozha majkă ljulkă pravi

F zilenă gura ljulekuvă,

Nă dve prăchki ljulekuvi,

Dă si ljule bjală Bogă.

Chem go ljule, pesne si pej.

Koj de je zăchu, sve pustuja,

Sve pustuja, sve puslusha...

(Iliev, 1889, 81, 57).

(God's mother makes a cradle

On the green lilac mountain,

Fastened to two twigs of lilac,

So as to swing the white God.

While swinging him she sings a lullaby;

Anyone who hears it, will stop any activity

And listen... ).

At another occasion Mary hides the young god high up in a tree where she swings it to sleep in a golden cradle:

Bozhja majka...

Kje si kachna... na edno drăfce,

$\mathrm{Na}$ edno drăfce... elchovo si.

Kat si kachna... zakachi si,

Zakachi si... zlatna ljulka,

Kje si gudi... mlada Boga.

Kat go gudi... zaljulja go,

Zaljulja go,... prispiva go,

Prispiva go,... zapjava...

(SbNU, 1889, VIII 11, 5).

(God's mother

mounts a tree,

a tree, a fir tree.

Mounting she hangs up a golden cradle,

to sing to the young god. 
Singing she rocks him,

swinging she sings a cradle song,

singing she lulls him into sleep... ).

Swinging the new-born child is a ritualistic precaution against evil and shall establish a magically balanced environment:

Ljuli mi, nani, m'shko dete,

ti da be rizik imalo,

ti ne bi sirak ostanalo,

na tri nedeli bez tatko,

na tri meseca bez majka!

(Penushliski, 1983, 13).

(Swing, my child,

for good luck,

and not become an orphan,

three weeks without your father,

three months without your mother!).

As folkloristic texts suggest, swinging the baby is not only an integral part of the ritual cycle of human life on the Balkans but has also been adopted by the myths about the fairy women and Mary.

\section{Swinging - the Fairy Women's Pastime}

From above the clouds the seven fairy ladies glide down to earth on the rays of the sun to swing. When the maiden Dona steps into the shade of the maple-tree beneath the fairy ladies' swing, its motion will transport her into the abysmal land of the Dead:

Vrni mi se Dono,

Vrni mi se, mila!

Nemoj mi si idi

Ovde pod drvoto;

Oti kje zaginiš

Mlada i zelena.

Tuva mi si ima

Sedum samovili,

Ljuljka si vrzuvat,

Tebe mi te chekat.

(Miladinovci, 1983, 8).

(Go back, Dona,

go back, my dear!

Do not step under the tree;

you will die,

young and green. 
Here are

the seven samovili,

fastening their swing,

waiting for you).

Young Stojna, a mother in childbed, will swing with the fairies on their golden swings into the land where the sun sets:

De mi dunacha, dunacha,

zimni studeni vetrove,

dunacha Stojna nevesta,...

v'v Pirin, stara planina,

na pirinskite ezera,

k'de se judi ljulecha.

Stara í Juda govori:

Stojninke, charna nevesto,

ela se, Stojne, poljulej

na nashite zlatni ljulki...

(Penushliski, 1983, 13).

(Cold winter winds were blowing,

lifting young Stojna

up to the old Pirin mountains,

to the Pirin lakes,

where the judi were swinging.

The old Juda said:

Stojna, lovely bride,

Come, Stojna, swing

on our golden swings... ).

At another occasion two young fairy mothers invite the maiden Jova to join them so as to bathe and swing their new-born children:

Tuku stana, ta si ojde

Na planina, na Vlaina,

Na samovilsko ezere.

Tamo najde dve nevesti,

Tamo najde dve nevesti,

dve nevesti, samovili,

de banaa malki deca,

malki deca pelenchina.

Ta na Jova govorea:

Sestrice le, mori Jovo, ajde, Jovo, s nas da idesh, da ni banash mashki deca, da gi banash da gi lulash, malki deca pelencheta...

(Sazdov, 1982, 37). 
(...Jova climbed the mountains to find the samovila lake. There she met two young samovila mothers bathing their new-born children. They invited Jova to come with them to nurse and swing their offspring).

When they finally come to get her at Annunciation after a set period of time they carry her off right from the swings:
Josh ja malo pochekaa,
Ta preigra Lazarica,
Lazarica i Velikden,
i ubavi den Gjurgjovden,
pa dojdoa na Spasovden,
na Spasovden na soboro,
na soboro na lulkite,
zamaglia, zaprashija,
moma Jova izvishija
vishom nebo pod oblaci
(Sazdov, 1982, 37).

(They let Jova dance through Lazarica, Veligden and Gjurgjovden but at Annunciation they arrived in a mist of clouds at the festive swinging and lifted her high up into the sky, right under the clouds).

\section{Conclusion}

Swinging is a ritual practice to ensure the general human well-being and stimulate the revival of nature. Thereby it predominantly involves young females and males as initiants in the pre-marriage rite and new-born humans in need of magic balancing. Furthermore, the swinging motion from east to west, while offering access to the Other World, results in a stabilization of the cosmic environment.

\section{LITERATURE}

ARNAUDOV, M. (1943). Bălgarski narodni praznici. Sofija.

DECHEVA, M. and A. Komitska (1999). Zwischen dem Sichtbaren und dem Unsichtbare. Historische Kalenderbräuche aus Bulgarien. Kittsee.

DIETRICH, W. Kahl, and G. TH. SARROS. (2001). Volkskundliche Studie eines aromunischen Dorfes im Pindos-Gebirge (Panagia, Distrikt Trikala). Thessaloniki.

ELIADE. M. (2009). Rites and Symbols of Initiation. The Mysteries of Birth and Rebirth. Putnam.

ELIADE, M. (2004). Shamanism. Archaic Techniques of Ecstasy. Princeton.

FRAZER, J. G. (1987). The Golden Bough. A Study in Magic and Religion. London.

FRAZER, J. G. (1919). Swinging as a Magical Rite. London. 
GIMBUTAS, M. (1992). The Goddesses and Gods of Old Europe. Myths and Cult Images. University of California Press.

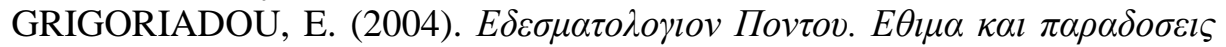

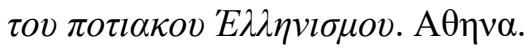

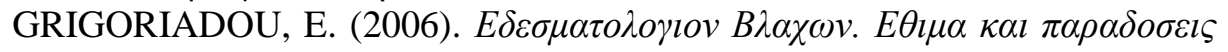
$\tau \omega v B \lambda \alpha \chi \omega v$. A $\theta \eta v \alpha$.

ILIEV, A. T. (1889). Sbornik ot narodni umotvorenija, obichai i dr., săbrani iz razni bălgarski pokrajnini. Kniga I. Sofija.

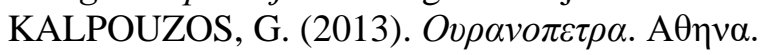

KOMI NARODNYE PESNI. (1968). Vyp. 2. Izma i Pechora. Syktyvkar.

KONAKOV, N. D. (1993). Ot Svjatok do Sochelnika. Komi tradicionnye kalendarnye obrjady. Syktyvkar.

MILADINOVCI, D. i K. (1983). Zbornik na narodni pesni. Skopje.

N 66: Kul'tura Barenceva Regiona, 2/97.

NANEVSKI, D. (1971). Ljubovni narodni pesni. Skopje.

NILSSON, M. P. (1950). The Minoan-Mycenaean religion and its survival in Greek religion. Lund.

PENUSHLISKI, K. (1983). Makedonski narodni baladi. Skopje.

PROPP, V. J. (1963). Russkie agrarnye prazdniki. Leningrad.

RISTESKI, M. (1985). Makedonski obredi i obredni pesni. Skopje.

SAZDOV, T. (1982). Na tenka srma nizhani. Narodni umotvorbi od Pirinska Makedonija. Skopje.

SHAPKAREV, K. A. (1976). Izbrani dela, obichai, obredi, nosii 4. Skopje.

SHARAPOV, V. E. and D. A. NESANELIS (1995). Evropejskij sever: vzaimodejstvie kul'tur $v$ drevnosti $i$ srednevekov'e. Materialy po archeologii Evropejskogo Severo-Vostoka. 14, 178-184. Syktyvkar.

SHARAPOV, V. E. and D. A. NESANELIS (1997). Theme of "Swinging" in Shamanism and Folk Culture. Syktyvkar. Leningrad.

SHTERNBERG, L. J. (1936). Pervobytnaja religija $v$ svete ètnografii.

SbNU - Sbornik za narodni umotvorenija, nauka i knizhnina (1889). Sofija.

STOIN, V. (1928). Narodni pesni ot Timok do Vita. Sofija.

VAN DE BOGART, W. G. (2013). The Giant Swing (Lo Ching Cha): Brahmanical Origins and Its Significance to Religious Culture of Thailand. Contemporary Socio-Cultural and Political Perspectives in Thailand [s.n.].

VRANSKA, C. (1940). Apokrifite za bogorodica $i$ bălgarskata narodna pesen. Sbornik na bălgarskata akademija na naukite, kniga XXXIV, 18, Sofija.

Герлинде Гласер

\section{ЛУЛАЊЕТО: РИТУАЛ ЗА ЗДРАВЈЕ И НАПРЕДОК ВО РУСИЈА И НА БАЛКАНОТ}

Резиме

Лулањето не само што го симболизира пролетното будење на природата, туку тоа исто така ја поттикнува плодноста на почвата. Динамичката конструкција на 
големата велигденска лулашка се темели на митот на премостот од овој свет во оној свет, а тајниот ритуал на местењето на лулашките, како и учеството во еротски игри, упатува на симболичко преосмислување на космогониските митови. Во светот на традиционалната култура, лулањето може да се смета за обид за надминување на судбинската неодреденост. 